\section{Pearl millet blast disease caused by Pyricularia pennisetigena in western arid Rajasthan, India}

\author{
S. K. Singh*, R. K. Solanki and R. K. Kakani \\ Division of Plant Improvement and Pest Management, \\ Central Arid Zone Research Institute, Jodhpur 342 003, India
}

Pearl millet is an important cereal crop grown for grain and fodder in arid and semi-arid regions of India. Pyricularia grisea (teleomorph: Magnaporthe grisea) is known to cause devastating foliar blast disease leading to reduction in grain and fodder yields in pearl millet. Internal transcribed spacer sequencing of ribosomal DNA revealed that the foliar blast of pearl millet in western arid Rajasthan, India, is caused by Pyricularia pennisetigena. Multiple sequence alignment validated that the reference sequence of $P$. pennisetigena from USA, aligned well with that of our sequence of $P$. pennisetigena. Phylogram clearly delineated $P$. grisea and $P$. penniseticola as phylogenetically separate species of Pyricularia compared to $P$. pennisetigena. Therefore concerted efforts are needed to develop resistant varieties and hybrids in pearl millet against $P$. pennisetigena in future plant breeding programmes, particularly for western arid Rajasthan. In addition, isolate CZPMP-17, molecularly identified as Colletotrichum sublioneola isolated from $P$. glaucum causing foliar disease is shown to be a pathogen of pearl millet.

Keywords: Arid region, geographical diversity, leaf diseases, pearl millet, Pennisetum glaucum.

PEARL millet (Pennisetum glaucum (L.) R. Br.) an important nutri-cereal crop is grown for grain, stover and green fodder in arid and semi-arid regions of Africa, America and Asia ${ }^{1}$. India is the largest producer of pearl millet occupying an area of $8.16 \mathrm{~m}$ ha, of which $4.618 \mathrm{~m}$ ha (56\% acreage) lies in Rajasthan and $3.378 \mathrm{~m}$ ha $(73 \%$ acreage) is in the hot western arid regions. Mainly five states (Rajasthan, Maharashtra, Gujarat, Uttar Pradesh and Haryana) account for nearly $95 \%$ of the pearl millet cultivation area. The national production of pearl millet is $9.363 \mathrm{Mt}$, whereas from the arid regions it is $2.324 \mathrm{Mt}$; the productivity of arid areas is low compared to other regions ${ }^{2}$. Over the years, foliar blast disease incidence in pearl millet has increased in the arid regions significantly reducing both the grain and fodder yields. Therefore, it is imperative to develop cultivars with blast resistance.

The identification and species designation of microorganisms based on morphological criteria is often not reliable due to significant morphological, physiological, pathogenic and or genetic diversity ${ }^{3,4}$. Nevertheless mole-

*For correspondence. (e-mail: sksingh1111@hotmail.com) cular techniques, especially PCR-based DNA approaches are rapid and consistent in identifying precisely species designation and resolving taxonomic chaos ${ }^{5}$. Internal transcribed spacer (ITS) sequence polymorphism of highly conserved rRNA gene region is a robust genetic marker due to higher evolutionary changes and least functional limitations for molecular diagnostics ${ }^{6,7}$, and genetic diversity both at inter- and -intra specific levels ${ }^{8,9}$.

During 2019, blast incidence was severe in various parts of the western arid regions of Rajasthan due to high rainfall compared to the regional average. Surveys of pearl millet disease were conducted in Barmer, Jaisalmer, Jalor, Jodhpur, Nagaur and Pali districts of western arid Rajasthan during the rainy season of 2019. Foliage samples were collected in paper bags and brought to the laboratory. The infected leaf and stem tissues showing symptoms of fungal infection were cut in small bits of approximately $1.5 \mathrm{~cm}$ size and chemically surface-sterilized by dipping in $1 \%$ sodium hypochloride $(\mathrm{NaOCl})$ solution in petri plates, washed in sterilized distilled water thrice and subsequently aseptically transferred onto pre-sterilized and solidified carrot agar culture medium (Hi Media) prepared by dissolving $19 \mathrm{~g}$ of carrot agar medium in 1 litre of distilled water and sterilizing it by autoclaving at $15 \mathrm{lbs}$ pressure $\left(121^{\circ} \mathrm{C}\right)$ for $15 \mathrm{~min}$. The petri plates were incubated at $28^{\circ} \mathrm{C}$ for five days in a BOD incubator. The growing mycelia tips were transferred along with some culture medium in the test tubes containing pre-sterilized carrot agar medium slants and again incubated in the BOD incubator for a week and stored in a refrigerator until used.

Field soil (sandy loam) was sterilized by autoclaving in polypropylene bags at $121^{\circ} \mathrm{C}$ for $1 \mathrm{~h}$ for two consecutive days and filled in $2 \mathrm{~kg}$ of sterilized soil in plastic pots of polyvinyl chloride (PVC). Pearl millet foliar blastsusceptible genotype ICMA 08333 was sown in these pots, and placed in the growth chamber and watered regularly. Each isolated pathogen was raised in conical flasks containing $100 \mathrm{ml}$ of pre-sterilized malt extract dextrose broth culture medium ( $10 \mathrm{~g}$ malt extract, $5 \mathrm{~g}$ dextrose in 1 litre of sterilized distilled water) for two weeks. Mycelial mat of each flask was diluted with sterilized distilled water and blended sufficiently to obtain conidial and mycelial suspension by filtering it with the help of four-layered muslin cloth. Pathogenicity tests were performed on three-week-old plants by spraying conidial suspension of specified isolate and by covering the pots for $12 \mathrm{~h}$ with a polythene sheet to maintain high humidity $(80-90 \%)$ in order to facilitate disease development. A total of three pots were inoculated with each isolate. Leaf symptoms were recorded, and each pathogen was reisolated and its pathogenicity was confirmed.

Each fungal culture was grown on malt extract-glucose broth culture medium (10 g malt extract, $5 \mathrm{~g}$ glucose per litre) for eight days at $28^{\circ} \mathrm{C}$. The genomic DNA was isolated by crushing fresh fungal mycelia with a 
micro-pestle in liquid nitrogen in $1.5 \mathrm{ml}$ micro centrifuge tubes. Hi Pura ${ }^{\circledR}$ plant minikit (Hi Media Laboratories, India) was used for DNA isolation following the protocols suggested by Birren and $\mathrm{Lai}^{10}$, and Sambrook et $a l .{ }^{11}$. The polymerase chain reaction (PCR) universal primers ITS-1 and ITS-4 were used to amplify the 5.8S rRNA gene regions ${ }^{7}$. PCR amplification was performed using thermal cycler (Corbett Research, USA) following PCR conditions ${ }^{12}$. The PCR products were run on $1.4 \%$ $(\mathrm{w} / \mathrm{v})$ pre-stained agarose gel with ethidium bromide in tris-acetic acid EDTA (1× TAE) buffer at $60 \mathrm{~V}$ for $100 \mathrm{~min}$, and visualized under UV light using syngene gel documentation system.

The sequencing of PCR amplified products was done employing ITS-1 (forward) and ITS-4 (reverse) universal primers separately using ABI Prism DNA sequencer (Applied Biosystems, USA). ITS-4 data were reverse-complimented to obtain complete sequences of the entire $5.8 \mathrm{~S}$ rRNA gene together with the encompassing ITS regions. The molecular diagnosis of each fungal culture was done on the basis of maximum similarity with that of the bestaligned reference sequence of Basic Local Alignment Search Tool (BLAST) of National Centre of Biotechnology Information (NCBI), USA. The complete rDNA sequences of ITS-1 and ITS-2 encompassing the 5.8S gene region of all the 21 pathogenic fungi isolated from foliage of pearl millet were deposited to NCBI database and GenBank Accession numbers obtained. Multiple sequence alignment of blast pathogen was performed using clustalX 1.83 software. The phylogenetic relationships of blast pathogen in relation to the other reference sequences of Pyricularia species were established by generating a phylogram using TreeView software ${ }^{13}$ based on nucleotide polymorphisms in the ITS region of the $5.8 \mathrm{~S}$ ribosomal nuclear DNA.

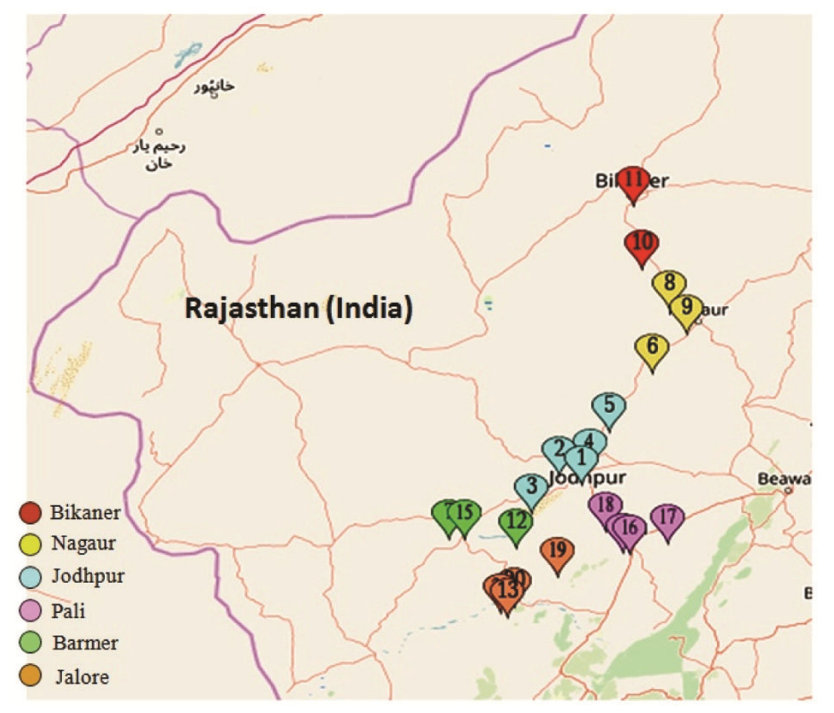

Figure 1. Pearl millet foliar disease collection sites from western arid region of Rajasthan, India.
Figure 1 shows a geographical map of foliage sample collection sites from six districts of the Western arid region of Rajasthan. The typical symptoms of blast disease appear as small lesions on the leaves. With advancement of the disease, these expand and turn necrotic with extensive chlorosis resulting in drying of young leaves (Figure 2). Figure 3 shows a pearl millet plant severely infected by blast disease. Figure 4 is a photomicrograph depicting close-up view of typically obpyriform conidia of Pyricularia pennisetigena.

Table 1 shows the results of molecular identification of fungal pathogens isolated from pearl millet foliage from six districts of western arid Rajasthan. Among 21 samples molecularly identified, 16 were designated as Pyricularia pennisetigena, three as Curvularia penneseti, and one each as Colletotrichum sublioneola and Colletotrichum $\mathrm{sp}$. The intra-species diversity among $16 \mathrm{P}$. pennisetigena and their phylogenetic relationships with the reference sequences of other Pyricularia species, viz. $P$. grisea KM484880, $P$. penniseticola KM484925 and $P$. pennisetigena KM484937 are shown in a phylogram generated based on nucleotide polymorphisms in the ITS region of the 5.8S ribosomal nuclear DNA (Figure 5).

The species of genus Pyricularia cause foliar blast disease in rice, wheat and grasses ${ }^{14}$. Foliar blast caused by Pyricularia grisea (Cooke) Sacc. [teleomorph: Magnaporthe grisea (Herbert) Barr)], is a well-known devastating fungal disease leading to reduction in grain and fodder yields in pearl millet ${ }^{15,16}$. Since several decades concerted efforts are being made for the development of

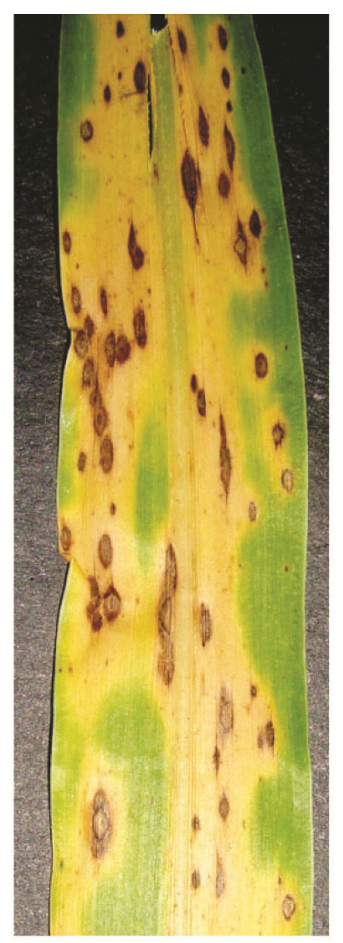

Figure 2. Close-up view of blast-infected pearl millet leaf. 


\section{RESEARCH COMMUNICATIONS}

Table 1. Molecular identification and GenBank accessions of 21 pathogenic fungi isolated from pearl millet representing western arid region of Rajasthan, India

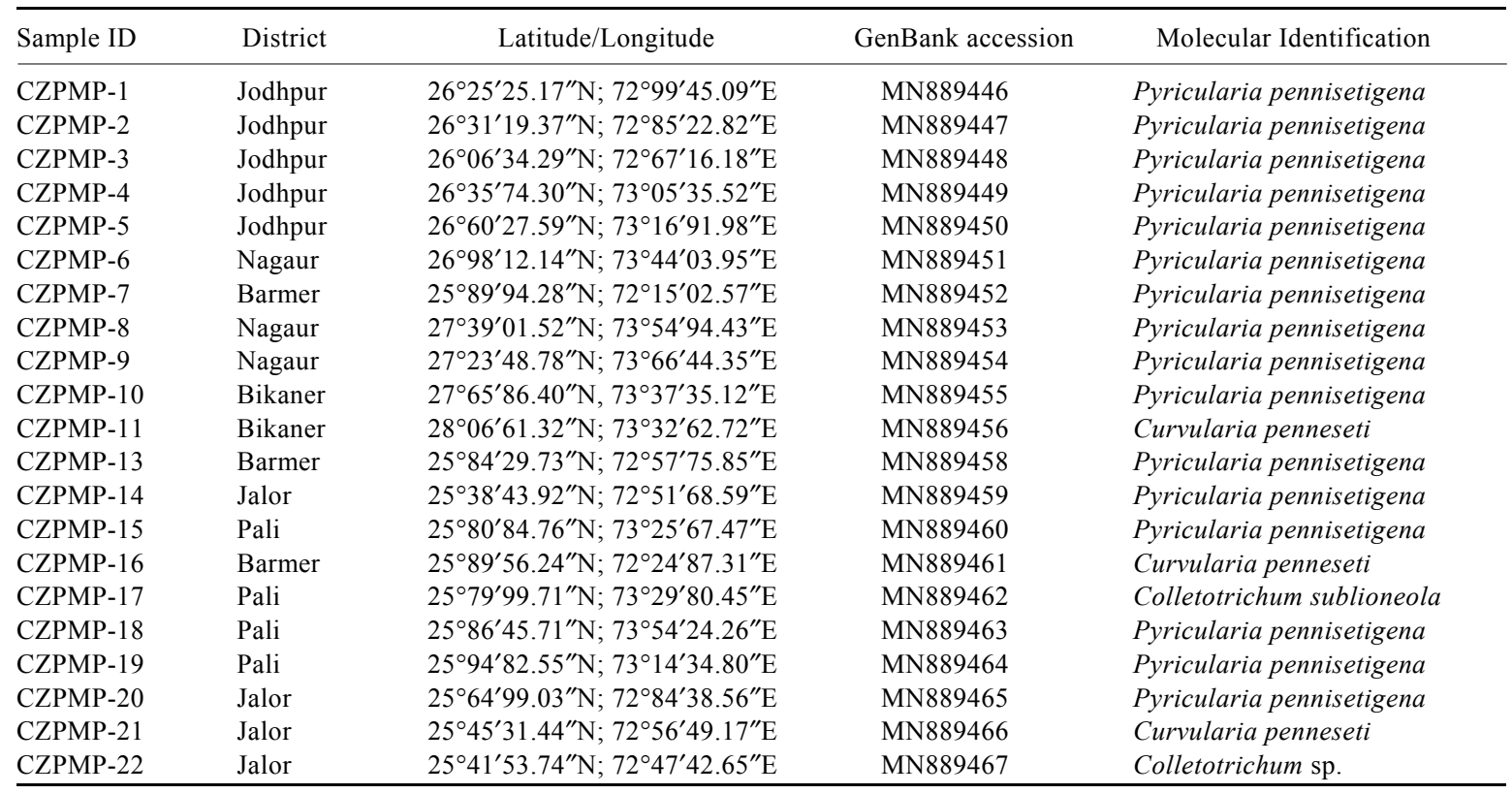

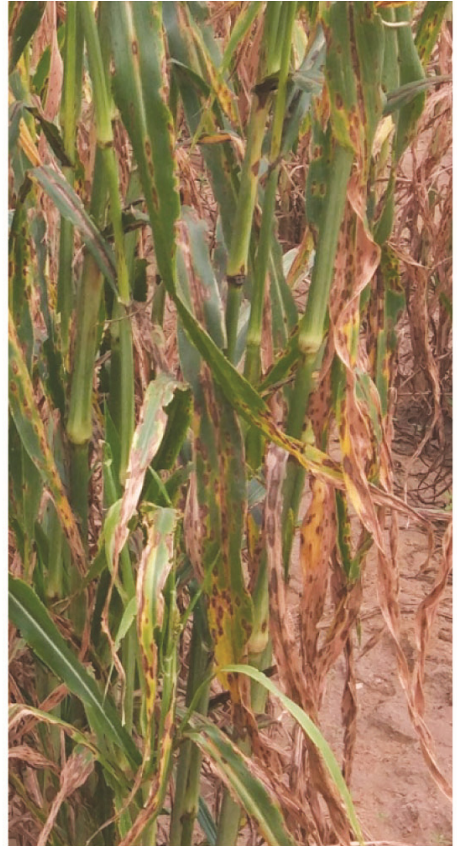

Figure 3. Field view of severely blast-infected pearl millet plant.

screening techniques and identification of resistance sources against foliar blast in pearl millet targeting a single Pyricularia species, viz. P. grisea $^{17-20}$.

DNA sequencing results clearly demonstrate that the causal agent of foliar blast disease of pearl millet in western arid Rajasthan is Pyricularia pennisetigena, which is phylogenetically a completely different species Pyricularia. This is validated by a phylogram generated upon multiple sequence alignment of $16 \mathrm{P}$. pennisetigena

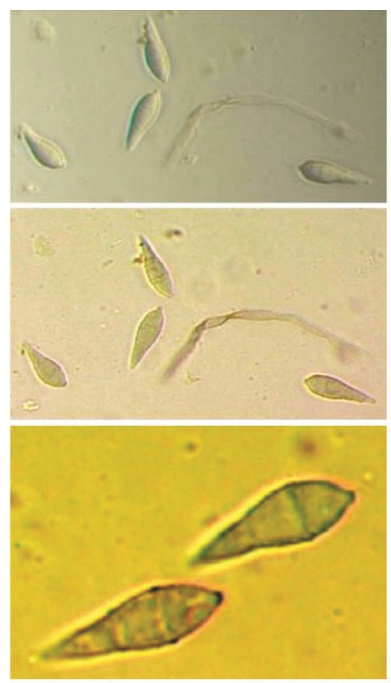

Figure 4. Close-up view of typically obpyriform conidia of Pyricularia pennisetigena.

sequences with those of available NCBI reference sequences of $P$. grisea KM484880, $P$. penniseticola KM484925 and $P$. pennisetigena KM484937. The phylogram exhibited that the reference sequence KM484937 of $P$. pennisetigena although reported from USA, aligned well with that of our sequences of $P$. pennisetigena. Whereas phylogenetic clade with bootstrap values revealed that $P$. penniseticola and $P$. grisea are phylogenetically quite separate species of Pyricularia compared to that $P$. pennisetigena.

Scanty literature reveals that there is no published record of $P$. pennisetigena causing blast disease in 


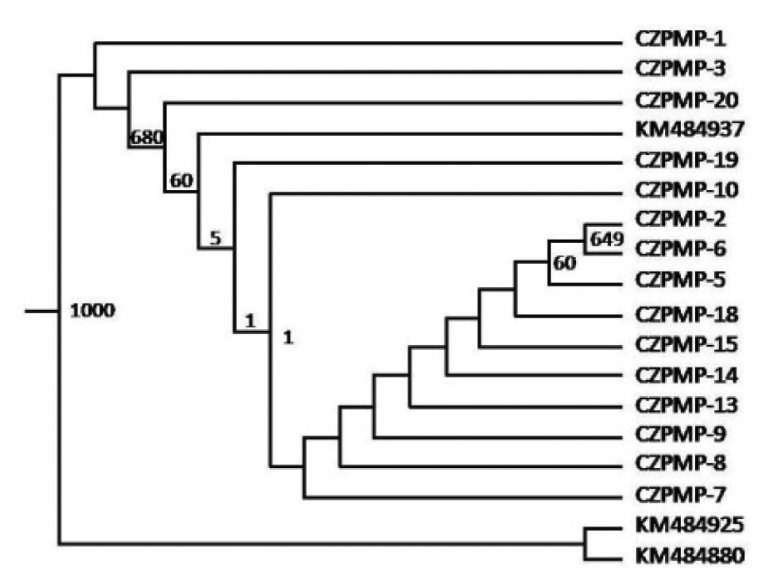

Figure 5. Phylogram generated using Neighbor Joining plot of multiple sequence aligned rRNA gene region of Pyricularia pennisetigena isolates along with reference sequences of $P$. grisea, Pyricularia penniseticola and $P$. pennisetigena.

P. glaucum from the western arid region of Rajasthan, except the one from USA by Klaubauf et $a l .^{21}$. They also reported $P$. pennisetigena as a pathogen from other cereal hosts; Cenchrus echinatus and Echinochloa colona (Brazil), Cenchrus ciliaris (Japan), other Pennisetum sp. (Mali) and Cenchrus echinatus (Philippines). Klaubauf et al. ${ }^{21}$ also emphasized on resolving the polyphyletic nature of Pyricularia (Pyriculariaceae), and that host range and/or conidium morphology cannot be used as a taxonomic criterion without extensive pathotyping. They proposed reevaluation of the species concept within Pyriculariaceae based on morphological and phylogenetic data. Zheng et $a l^{22}$, on the basis of comparative genomic analysis of $P$. oryzae and $P$. penniseti, suggested that $P$. penniseti (P1609) could be a useful resource for the genetic study of the Pennisetum-infecting Pyricularia species.

The isolate CZPMP-17 molecularly identified as Colletotrichum sublioneola and isolated from P. glaucum causing foliar disease is a pathogen of pearl millet. However C. sublioneola as a pathogen causing anthracnose disease in sorghum is well-known as one of the most important fungal diseases which can cause substantial grain yield losses in sorghum ${ }^{23-25}$. The isolates CZPMP-11, 16 and 21 were molecularly identified as Curvularia penneseti and are known to cause foliar disease in pearl millet $^{26}$.

The present study reveals that the causal agent of foliar blast disease of pearl millet in arid western Rajasthan is $P$. pennisetigena, which is phylogenetically completely a different species of Pyricularia. Therefore, concerted efforts must be made to develop resistant varieties and hybrids in pearl millet against $P$. pennisetigena in future plant breeding programmes, particularly for western arid Rajasthan. Also, C. sublioneola isolated from P. glaucum causing foliar disease has been recorded as a pathogen of pearl millet in this study.
1. Thakur, R. P., Sharma, R., Rai, K. N., Gupta, S. K. and Rao, V. P., Screening techniques and resistance sources for foliar blast in pearl millet. J. SAT Agric. Res., 2009, 7, 1-5.

2. Solanki, R. K., Mahla, H. R., Kakani, R. K., Choudhary, K. B. and Sharma, R., Stress tolerant crop varieties of major arid zone crops to promote resilience to climatic stresses. Indian Farm., 2018, 68(9), 41-45.

3. Mayek-Perez, N., Lopez-Castan, C. and Gonzalez-Chavira, M., Variability of Mexican isolates of Macrophomina phaseolina based on pathogenesis and AFLP genotype. Physiol. Mol. Plant Pathol., 2011, 59, 257-264.

4. Singh, S. K., Sharma, V. P., Sharma, S. R., Kumar, S. and Tiwari, M., Molecular characterization of Trichoderma taxa causing green mould disease in edible mushrooms. Curr. Sci., 2006, 90(3), 427431.

5. Aghakhani, M. and Dubey, S. C., Determination of genetic diversity among Indian isolates of Rizoctonia bataticola causing dry root rot of chickpea. Antonie van Leeuwenhoek, 2009, 96, 607619.

6. Alvarez, I. and Wendel, J, F., Ribosomal ITS sequences and plant phylogenetic inference. Mol. Phylogenet. Evol., 2003, 29, 435455 .

7. White, T. J., Bruns, T. and Taylor, J., Amplification and direct sequencing of fungal ribosomal RNA genes for phylogenetics. In PCR Protocols: A Guide to Methods and Applications (eds Innis, M. A. et al.), Academic Press, San Diego, CA, USA, 1990, pp. 315-322.

8. Gautam, R., Singh, S. K. and Sharma, V., Molecular diagnosis and intraspecific genetic variability of root pathogens of arid legumes in Western Rajasthan, India. Rev. Biol. Trop., 2016, 64(4), 15051518.

9. Singh, S. K., Doshi, A., Pancholy, A. and Pathak, R., Biodiversity in wood-decay macro-fungi associated with declining arid zone trees of India as revealed by nuclear rDNA analysis. Eur. J. Plant Pathol., 2013, 136, 373-382.

10. Birren, B. and Lai, E., Pulsed Field Gel Electrophoresis: A Practical Guide, Academic Press, San Diego, USA, 1993, p. 253.

11. Sambrook, J., Fritsch, E. F. and Maniatis, T., Molecular Cloning: A Laboratory Manual, Cold Spring Harbor Laboratory Press, NY, USA, 1989, 2nd edn.

12. Gautam, R., Singh, S. K. and Sharma, V., RAPD and nuclear rDNA ITS polymorphism within Macrophomina phaseolina isolated from arid legumes of western Rajasthan. Proc. Natl. Acad. Sci. India Sect. B, 2013, 84(1), 171-181.

13. Page, R. D. M., Tree view: an application to display phylogenetic on personal computers. Comput. Appl. Biol. Sci., 1996, 12, $357-$ 358 .

14. Klaubauf, S., Tharreau, D., Fournier, E., Groenewald, J. Z., Crous, P. W. and de Vries, R. P., Molecular taxonomy of Magnaporthe and Pyricularia species. In Translation for Genomics to Disease Management, 6th International Rice Blast Conference, Jeju, South Korea, 20-24 August 2013.

15. Wilson, J. P. and, Gates, R. N., Forage yield losses in hybrid pearl millet due to leaf blight caused primarily by Pyricularia grisea. Phytopathology, 1993, 83, 739-743.

16. Wilson, J. P. and Hanna, W. W., Effects of gene and cytoplasm substitutions in pearl millet on leaf blight epidemics and infection by Pyricularia grisea. Phytopathology, 1992, 82, 839-842.

17. Chandra Nayaka, S. et al., Magnaporthe Blast of Pearl Millet in India - Present Status and Future Prospects, All India Coordinated Research Project on Pearl Millet (Indian Council of Agricultural Research), Jodhpur, 2017, p. 51.

18. Hanna, W. W. and Wells, H. D., Inheritance of pyricularia leaf spot resistance in pearl millet. J. Hered., 1989, 80, 145-147.

19. Thakur, R. P., Sharma, R. and Rao, V. P., Screening techniques for pearl millet diseases. Information Bulletin No. 89, International 
Crops Research Institute for the Semi-Arid Tropics (ICRISAT), Patancheru, 2011, p. 56.

20. Wilson, J. P., Wells, H. D. and Burton, G. W., Inheritance of resistance to Pyricularia grisea in pearl millet accessions from Burkino Faso and inbred Tift 85DB. J. Hered., 1989, 80, 499-501.

21. Klaubauf, S., Tharreau, D., Fournier, E., Groenewald, J. Z., Crous, P. W., Vries, R. P. de and Lebrun, M. H., Resolving the polyphyletic nature of Pyricularia (Pyriculariaceae). Stud. Mycol., 2014, 79, 85-120.

22. Zheng, H. et al., Comparative genomic analysis revealed rapid differentiation in the pathogenicity-related gene repertoires between Pyricularia oryzae and Pyricularia penniseti isolated from a Pennisetum grass. BMC Genomics, 2018, 19, 927.

23. Ngugi, H. K., Julian, A. M., King, S. B. and Peacock, B. J., Epidemiology of sorghum anthracnose (Colletotrichum sublineolum) and leaf blight (Exserohilum turcicum) in Kenya. Plant Pathol., 2000, 49, 129-140.

24. Sutton, B. C., The Coelomycetes, Commonwealth Mycological Institute, Kew, UK, 1980.

25. Thomas, M. D., Sissoko, I. and Sacco, M., Development of leaf anthracnose and its effect on yield and grain weight of sorghum in West Africa. Plant Dis., 1996, 80, 151-153.

26. Narayana, H. S. and Monga, A. K., Antagonism between saprophytic and pathogenic species of Curvularia. Curr. Sci., 1980, 49(18), 713-714.

ACKNOWLEDGEMENT. We thank the Director, ICAR-Central Arid Zone Research Institute, Jodhpur, for providing the necessary research facilities and encouragement.

\section{Fine roots dynamics and biomass of Phyllanthus emblica-based agroforestry system in Bundelkhand region of Central India}

\author{
Dhiraj Kumar ${ }^{1,3, *}$, Ram Newaj ${ }^{1}$, Asha Ram ${ }^{1}$, \\ Rajendra Prasad ${ }^{1}$ and Veeresh Kumar ${ }^{2}$ \\ ${ }^{1}$ ICAR-Central Agroforestry Research Institute, Gwalior Road, \\ Near Pahuj Dam, Jhansi 284 003, India \\ ${ }^{2}$ ICAR-National Bureau of Agricultural Insect Resources, \\ Bengaluru 560 024, India \\ ${ }^{3}$ Present address: ICAR-Indian Institute of Soil Science, \\ Berasia Road, Nabibagh, Bhopal 462 038, India
}

Fine roots are the most important contributors of ecosystem productivity in many terrestrial ecosystems. However, its dynamics, biomass potential, production and turnover rates of fine roots under different envi-

\footnotetext{
*For correspondence. (e-mail: dhiraj.iari@gmail.com)
}

ronments lack clarity. We have studied horizontal and vertical distribution of fine root dynamics, including length, density, biomass, production and turnover rates in Phyllanthus emblica-based agroforestry system in stressed environment of red soil patch of Bundelkhand region in Central India. Nearly, $63 \%$ of the fine root length and its density are confined to 0 $45 \mathrm{~cm}$ soil depth. Fine root biomass significantly varied across seasons with $70-80 \%$ of the biomass obtained during autumn, followed by spring and summer seasons. The annual fine root production rates were highest near the stem base up to $1.0 \mathrm{~m}$ distance and the turnover rates varied from $1.63 \mathrm{yr}^{-1}$ (highest) at $0.5 \mathrm{~m}$ distance to $1.03 \mathrm{yr}^{-1}$ (lowest) at $1.5 \mathrm{~m}$ distance from the stem base. The fine root dynamics changed highly across seasons, indicating more vigorous vegetative growth and nutrient release during monsoon months. Thus, studies on fine root dynamics can improve our understanding of overall system productivity and management under stressed environments.

Keywords: Agroforestry system, fine root biomass, Phyllanthus emblica, turnover rates.

RooTs per se and fine roots in particular act as an integral part of the tree root ecosystem and play a crucial role for better resource acquisition. This in turn improves soil nutrients, organic matter, microbial niche development through their decomposition and turnover. In the improvement of soil health, roots provide carbon and nutrients by rapid turnover, intercept leached nutrients and recycle them to the surface ${ }^{1,2}$. It was observed that in five fruit trees and three forest tree species, nearly $80 \%$ of fine roots were confined to $0-20 \mathrm{~cm}$ soil layer ${ }^{3}$. Fine root biomass and productivity vary under different tree spacings ${ }^{4}$, seasons in the year ${ }^{5}$, intercrops ${ }^{6}$, nutrient level ${ }^{7}$ and soil depth ${ }^{2,3}$. In agroforestry systems, variation in spatial distribution of fine roots is crucial for competition and maximizing the absorption of both soil moisture and nutrients ${ }^{8}$. Thus, studies on fine roots are important in order to decipher belowground competition of resources in intercropped systems.

There are several reports on tree rooting pattern and biomass in the literature ${ }^{9-13}$, but relatively few studies on fine root length or biomass due to the effort involved in its measurement ${ }^{14,15}$. Alterations in fine root growth and its architectural traits may reflect upon the availability of soil resources ${ }^{16}$ and stand characteristics ${ }^{17}$. Thus, the fine roots proliferation within a stand may serve as a useful indicator for assessing stand productivity in reclaimed ecosystems ${ }^{18}$. In terrestrial ecosystems, processes associated with fine root dynamics such as production and turnover are considered to be some of the main drivers of bio-geochemical nutrient cycling and overall stand productivity $^{19-21}$. Nevertheless, fine root turnover may largely dictate, development of potentially long-term $\mathrm{C}$ storage pools in the organic matter of mineral soils ${ }^{22-24}$. Even 